Verstärkung der brüsken Bewegungen. Nach Vorbehandlung mit $3 \mathrm{mg} / \mathrm{kg}$ i.p. bzw. $2 \mathrm{mal} 3 \mathrm{mg} / \mathrm{kg}$ i.p. BOL-148 (27 und $3 \mathrm{Std}$ vor LSD-25) zeigt sich nach LSD-25 keine Verzögerung des Eintritts des Erregten Schlafes mehr, die Intensität der brüsken Bewegungen bleibt jedoch erhöht.

Die Resultate zeigen, daß BOL die für die erste Phase typischen LSD. Wirkungen nicht besitzt. Das kann in Zusammenhang mit dem nach LSD, jedoch nicht nach BOL gesenkten Umsatz von Serotonin gebracht werden [1]. Daß diese erste Wirkungsphase von LSD durch die Vorbehandlung mit BOL weitgehend abgeschwächt werden kann, wird als Antagonismus auf der Ebene des Receptors interpretiert. Die für LSD und BOL gleichsinnigen Effekte sind schwieriger zu interpretieren, könnten jedoch möglicherweise mit einer Beeinflussung zentral cholinerger Regulationen zusammenhängen.

\title{
Literatur
}

1. Lin, R. C., Ngai, S. H., Costa, E.: Science 166, 237 (1969).

2. Loew, D. M., Vigouret, J. M.: Un. Schweiz. Ges. exp. Biol., Mai 1969.

3. Michel, F., Klein, M., Jouvet, D., Valatx, J. L.: C. R. Soc. Biol. (Paris) 155, 2389 (1961).

Dr. D. M. Loew, Medizinisch-Biologische Forschung, Sandoz AG

CH-4000 Basel

\section{Histamine Methyltransferase in Salivary Glands and Gastric Mucosa of Man, Dog, Pig and Cow}

Histaminmethyltransferase in Speicheldrüsen und Magenschleimhaut von Mensch, Hund, Schwein und Rind

Lormaz, W., Barth, H., Fetrel, G., Werle, E.

In salivary glands and gastric mucosa high activities of histamine methyltranferase could be demonstrated (Table). The acitvity of the

Table. Activities of histamine methyltransferase in salivary glands and gastric mucosa

\begin{tabular}{llllll}
\hline Species & \multicolumn{3}{l}{$\begin{array}{l}\text { Enzyme activities in p-moles of histamine metabolized per min and } \\
\text { mg protein }\end{array}$} \\
\cline { 2 - 6 } & $\begin{array}{l}\text { Submaxillary } \\
\text { gland }\end{array}$ & $\begin{array}{l}\text { Parotid } \\
\text { gland }\end{array}$ & \multicolumn{2}{l}{ Gastric mucosa } & \\
\cline { 3 - 6 } & & & Fundus & Corpus & Antrum \\
\hline Man & 55.0 & $38,3 \pm 12,7$ & $171 \pm 50$ & $61 \pm 30$ & $209 \pm 51$ \\
Dog & $\mathbf{1 5 9 , 7 \pm 4 5 , 8}$ & $29,3 \pm 45,0$ & 122 & $73 \pm 22$ & $236 \pm 139$ \\
Pig & $\mathbf{1 2 0 , 3 \pm 6 8 , 8}$ & $\mathbf{6 5 , 3} \pm 14,0$ & $242 \pm 83$ & $216 \pm 15$ & $465 \pm 110$ \\
Cow & 323,0 & 266,0 & 42 & 23 & 52 \\
\hline
\end{tabular}

Mean values $\pm S$. D. from 2-7 determinations. In cows only the rennet-bag was investigated. 
enzyme was determined by the disappearence of histamine in the incubation mixtures in the presence of S-adenosylmethionine according to Lorenz et al. [1]. Histamine was measured spectrofluorometrically after isolation by ion exchange chromatography on Dowex 50 WX-8 and the specificity of the method was proved as described in [1].

Histamine methyltransferase from pig antrum was purified 6-fold by ultracentrifugation and fractional precipitation by ammonium sulfate (45-70\% saturation). The enzyme showed the following properties: $K_{m}$ for histamine $2,3 \cdot 10^{-5} \mathrm{M}, K_{m}$ for S-adenosylmethionine $4,3 \cdot 10^{-5} \mathrm{M}$, $\mathrm{pH}$-optimum 7,4. The occurrence of histamine methyltransferase in salivary glands and gastric mucosa supports the hypothesis that histamine is a physiological chemostimulator of parasympathetic salivary and gastric secretion $[2,3]$.

\section{References}

1. Lorenz, W, Barth, H., Werle, E.: Naunyn-Schmiedebergs Arch. Pharmak. (in press) (1970).

2. Lorenz, W., Haubensak, G., Hutzel, M., Werle, E.: Naunyn-Schmiedebergs Arch. Pharmak. exp. Path. 260, 416 (1968).

3. - Pfleger, K.: Klin. Wschr. 46, 57 (1968).

Priv.-Doz. Dr. W. Lorenz, Institut für Klinische Chemie und Klinische Biochemie der Universität München D-8000 München 15, Nußbaumstraße 20

Histamine Release in Man by Propanidid (Epontol ${ }^{\circledR}$ ), Gelatine (Haemaccel ${ }^{\circledR}$ ), Histalog, Pentagastrin and Insulin

Histaminfreisetzung beim Menschen durch Epontol ${ }^{\circledR}$, Haemaccel ${ }^{\circledR}$, Histalog, Pentagastrin und Insulin

Lormaz, W., Doentcke, A., Frifer, G., Messmer, K., Meter, R., Bennesch, L., Barth, H., Kusche, J., Hutzer, M., Werle, E.

In the blood plasma and gastric juice of 9 healthy, male students, histamine concentrations of $0.8 \pm 0.3 \mathrm{ng} / \mathrm{ml}$ and of $24.0 \pm 9.1 \mathrm{ng} / \mathrm{ml}$ (basal secretion) were determined. Histamine was measured spectrofluorometrically after isolation by ion exchange chromatography on Dowex $50 \mathrm{WX}-8$ followed by extraction into alkaline butanol [2]. The specifity of the method was proved by thinlayer chromatography, degradation by diamine oxidase (pig kidney) and histamine methyltransferase (guinea-pig brain), and by bioassay (guinea-pig ileum and cat blood pressure) [2].

$2,5,10$ and 15 min after the injection of Epontol ${ }^{\circledR}$ the histamine concentration of the venous plasma increased significantly by 100, 230, 160 